\title{
THE USE OF ACETONITRILE AS THE SOLE NITROGEN AND CARBON SOURCE BY GEOTRICHUM SP. JR1
}

\author{
Rachel Passos Rezende $^{3 *}$; João Carlos Teixeira Dias ${ }^{1}$; Andrea Souza Monteiroํㅜ Fernando Carraza²; \\ Valter Roberto Linardi ${ }^{1}$
}

\begin{abstract}
${ }^{1}$ Departamento de Microbiologia, Instituto de Ciências Biológicas, Universidade Federal de Minas Gerais, Belo Horizonte, MG, Brasil. ${ }^{2}$ Departamento de Química, Instituto de Ciências Exatas, Universidade Federal de Minas Gerais, Belo Horizonte, MG, Brasil. ${ }^{3}$ Departamento de Ciências Biológicas, Universidade Estadual de Santa Cruz, Ilhéus, BA, Brasil.
\end{abstract}

Submitted: March 12, 2003; Returned to authors: July 25, 2003; Approved: February 23, 2004.

\begin{abstract}
A yeast strain identified as Geotrichum sp. JR1 was able to use acetonitrile as the sole carbon and nitrogen source. The strain grew in 0.5 to $2 \mathrm{M}$ acetonitrile. Ammonia generation as enzymatic product during the strain growth indicates the presence of an acetonitrile degrading enzyme. Acetic acid and acetamide were detected during assays with the resting cells cultivated in acetonitrile, indicating the presence of nitrile and amide degrading enzymes. This paper is the first to describe the use of acetonitrile as the sole carbon and nitrogen source by a yeast.
\end{abstract}

Key words: Geotrichum sp., acetonitrile, degrading enzymes

\section{INTRODUCTION}

Nitriles posses the general structure R-CN, which may occur naturally or synthetically. They are used for the synthesis of plastics, cosmetics, pharmaceuticals, herbicides and other chemicals. Unfortunately, there is an increasing dissemination of acetonitrile in the environment via industrial waste waters, and toxic activity can occur (4).

Nitrile compounds are generally catabolized by microorganisms through direct conversion to carboxylic acids and ammonia using a nitrilase system (EC. 3.5.5.1) or nitrile hydratase (EC. 4.2.1.84) that form amide as an intermediate degradation product, followed by amidase (EC.3.5.1.4), that converts the amide to the corresponding carboxylic acid and ammonia. Furthermore, most of our knowledge of the biochemistry, regulation and genetics of degradative pathways of these compounds has been obtained from studies with bacteria $(6,7,11)$.

The widespread use of nitriles has created considerable commercial interest in nitrile-hydrating enzymes, both as biocatalysts in chemical syntheses (10) and as a means of biological detoxification of nitrile containing waste (13).

Few studies have been carried out on the use of nitriles by yeasts $(2,3,4,9,12)$. All these studies reported the use of nitriles and corresponding amides as the only nitrogen source. The present study describes the metabolism of acetonitrile by the yeast strain Geotrichum sp. JR1, which is the first yeast reported to use acetonitrile as the sole nitrogen and carbon source.

\section{MATERIALS AND METHODS}

\section{Microorganism}

The yeast strain employed in this study was isolated from a cyanide treatment bioreactor in a Brazilian Gold Mine (Mineração Morro Velho, Nova Lima, Brazil), where effluents cyanide concentration ranged from 150 to $300 \mathrm{ppm}$ (2). The microorganism was identified according to Kurtzman and Fell (8). The strain was maintained on GYMP agar slant medium ( $2 \%$ glucose, $0.5 \%$ yeast extract, $1 \%$ malt extract, $0.2 \mathrm{NaH}_{2} \mathrm{PO}_{4}$ and

\footnotetext{
* Corresponding author. Mailing address: Departamento de Ciências Biológicas, Universidade Estadual de Santa Cruz. 45650-000, Ilhéus, BA, Brasil.

E-mail: rachel@uesc.br
} 
$2 \%$ agar), under a layer of mineral oil, and was maintained at $4^{\circ} \mathrm{C}$ or in liquid nitrogen. Acetonitrile, acetamide and acetic acid were obtaneid from Merck (Darmstadt, Germany).

\section{Kinetics of the growth}

The inoculum for the experimental media was obtained from a yeast cell suspension in deionized water that was submitted to shaking for $24 \mathrm{~h}$ to prevent endogenous growth. A $0.5 \mathrm{~mL}$ of yeast suspension $\left(10^{6}\right.$ cell $\left.\mathrm{mL}^{-1}\right)$ was inoculated into $125 \mathrm{~mL}$ Erlenmeyer flasks holding $10 \mathrm{~mL}$ minimum medium $(0.1 \%$ $\mathrm{K}_{2} \mathrm{HPO}_{4}, 0.02 \% \mathrm{MgSO}_{4} 7 \mathrm{H}_{2} \mathrm{O}$ and $0.01 \% \mathrm{NaCl}$ ) containing acetonitrile from 0.5 up to $2 \mathrm{M}$. The flasks were incubated under shaking $(120 \mathrm{rpm})$ at $28^{\circ} \mathrm{C}$. At intervals of $24 \mathrm{~h}$, the samples were filtered through a $0.22 \mathrm{~mm}$ membrane (Millipore), and the supernatant was collected for analysis. Growth was estimated in terms of dry mass by drying the membrane for 48 $\mathrm{h}$ at $80^{\circ} \mathrm{C}$.

\section{Substrate consumption and product formation}

Substrate consumption and product formation were determined during growth and enzymatic assay (using resting cells) of Geotrichum sp. JR1 in acetonitrile as the sole nitrogen and carbon sources and by gas chromatography using a GC 5890 (Hewlett-Packard, series II) equipped with a flame ionization detector. The column used in this experiment was an FFAP (cross linked) with $25 \mathrm{~m}$ x $0.20 \mathrm{~mm}$ internal diameter $\mathrm{x} 0.33$ film thickness. The operational conditions were as follows: hydrogen as carrier gas, 15:1 split ratio, injection volume $-1 \mathrm{~mL}$, injector temperature $200^{\circ} \mathrm{C}$ and detector temperature $230^{\circ} \mathrm{C}$.

\section{Enzymatic assay}

The resting cells, obtained from culture in acetonitrile as the sole carbon source, were investigated for enzymatic activity by measuring the production of ammonia (5). The yeast cells were harvested by centrifugation (10 min., $5000 \mathrm{rpm}$ ), washed twice in a $10 \mathrm{mM}$ phosphate buffer ( $\mathrm{pH}$ 7.0). The assay was prepared with $6 \mathrm{mg}$ of the resting cells (dry weight) in $10 \mathrm{~mL}$ solution (10 $\mathrm{mM}$ phosphate buffer at $\mathrm{pH}$ 7.0) containing acetonitrile or acetamide. After assay, the yeast cells were harvested by centrifugation and ammonia was assayed in the supernatant (5). The supernatant was assayed in tubes containing $1.0 \mathrm{~mL}$ solution of acetonitrile or acetamide in $10 \mathrm{mM}$ sodium phosphate buffer at $\mathrm{pH} 7.0$ and $1.0 \mathrm{~mL}$ of supernatant at $30^{\circ} \mathrm{C}$. As a control process, the presence of ammonia was measured in the growth supernatant. To determine whether the enzyme system for nitrile metabolism was inducible or constitutive, the strain was subcultured ten times in YCB (Yeast Carbon Base) medium containing $0.1 \%$ ammonium sulfate. Enzymatic assays were made by varying $\mathrm{pH}$ from 3 to 5 in citrate buffer, from 6 to 8 in sodium phosphate buffer, and from 7 to 8 in Tris $\mathrm{HCl}$ buffer, and at $\mathrm{pH} 9$ in glicine buffer and at $\mathrm{pH} 10$ carbonate buffer. All buffer solutions were at $10 \mathrm{mM}$.

\section{RESULTS AND DISCUSSION}

Although Geotrichum sp. JR1 was able to grow under high acetonitrile concentrations $(1 ; 1.5$ and $2 \mathrm{M})$, the best growth rate was observed when the strain was grown in $0.5 \mathrm{M}$ acetonitrile (Fig. 1). The yeast Candida guilliermondii UFMG-Y 65 strain (4) used a maximum of 2.2 M acetonitrile as nitrogen source, but was not able to use this compound as carbon source. Between 48 and $72 \mathrm{~h}$, the growth varied according to acetonitrile concentration (Fig. 1). An inhibitory effect was observed in the first hours of growth, probably due to the toxic effect of acetonitrile and to the fact that the yeast was not adapted to this substrate. This fact has not been observed for Candida famata (9) when grown in high nitrile concentrations, because the strain was let to previously adapt to increasing concentrations of acetonitrile.

The enzyme systems were found to be inducible because the washed cells (intact) obtained after ten subcultures in Yeast Carbon Base (YCB) with $0.1 \%$ ammonia failed to hydrolyse acetonitrile or acetamide. The same result was reported by Dias et al. (4).

The activity of the nitrile degrading enzyme increased with the increase of incubation time and reached a maximum at $72 \mathrm{~h}$ of growth in $0.5 \mathrm{M}$ acetonitrile medium (Fig. 2). These results suggest that after $96 \mathrm{~h}$, even at high acetonitrile concentrations, the strain is adapted to use nitrile as sole nitrogen and carbon source (Fig. 2). A decrease (Fig. 3) in consumption of acetonitrile was observed with an increase in ammonia concentration, showing that acetonitrile degradation had occurred.

Assays with intact cells indicated that acetonitrile breakdown yielded acetic acid, acetamide as indicated by gas chromatography (Fig. 4) and ammonia. Acetic acid and ammonia were found in the reaction mixture whem acetamide was used as substrate for the enzyme system (data not shown). None of

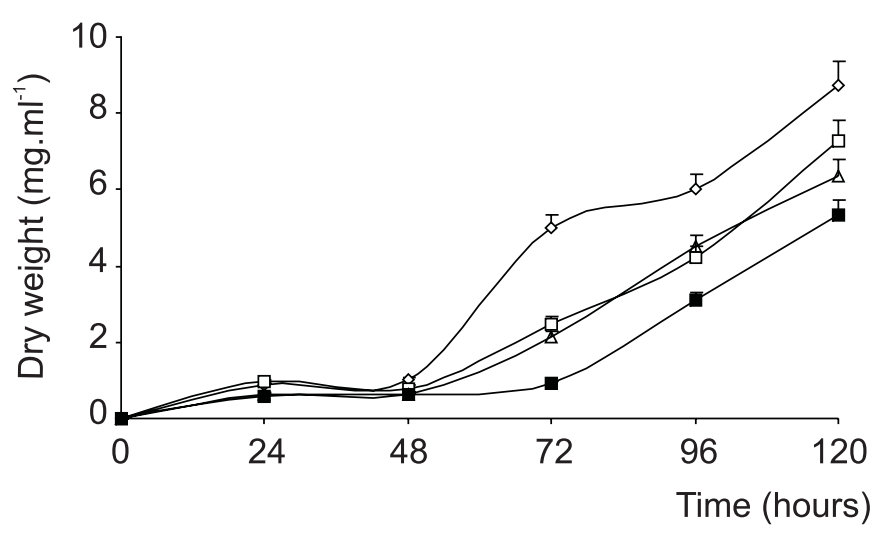

Figure 1. Kinetics of growth of Geotrichum sp. JR1 using different acetonitrile concentrations $(\square 2 \mathrm{M}, \triangle 1.5 \mathrm{M}, \square 1 \mathrm{M}$, $\diamond 0.5 \mathrm{M})$ 


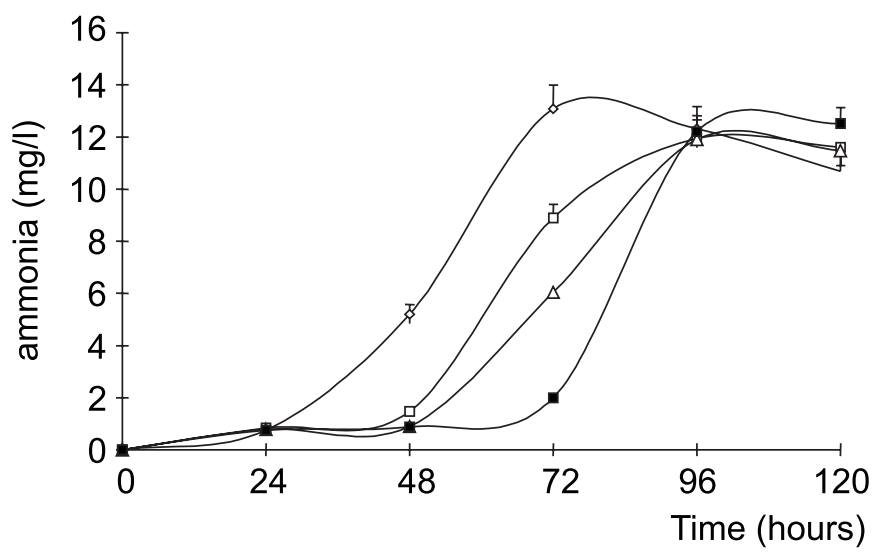

Figure 2. Kinetics of ammonia generation (5) during growth of Geotrichum sp. JR1 on different acetonitrile concentrations $2 \mathrm{M}, \triangle 1.5 \mathrm{M}, \square 1 \mathrm{M}, \diamond 0.5 \mathrm{M})$.

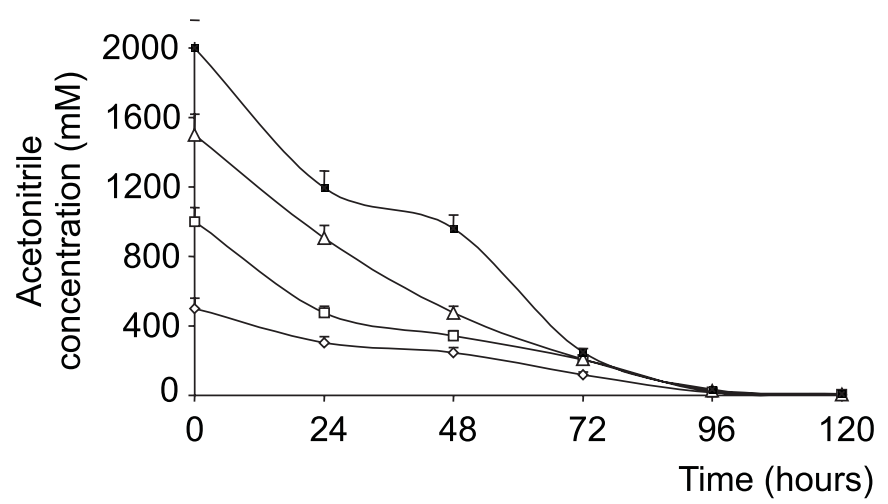

Figure 3. Kinetics of acetonitrile consumption (by gas chromatography analisys) during growth of Geotrichum sp. JR1 on different acetonitrile concentrations $(\square 2 \mathrm{M}, \triangle 1.5 \mathrm{M}$, $\square$ $1 \mathrm{M}, \diamond 0.5 \mathrm{M})$.

these metabolites was detected during growth, suggesting their rapid utilization as carbon and nitrogen source. Moreover, ammonia was always detected, showing acetonitrile breakdown. These facts strongly suggest that acetonitrile was the sole carbon and nitrogen source.

The acetonitrile degrading enzyme system by Geotrichum sp. JR1 suggests the presence of nitrile hydratase and amidase. Generally, it has been suggested that simple aliphatic nitriles are metabolized in a two-step process by nitrile hydratase and amidase (1). Rezende et al. (12) reported a nitrile degrading enzyme that shows the presence of nitrile hydratase and amidase and demonstrated acid and amide formation during propionitrile degradation by Cryptococcus sp UFMG-Y28. The ability of Geotrichum sp. JR1 to produce ammonia over a wide range of $\mathrm{pH}$ values (3 to 10 ) at high acetonitrile concentration (data not

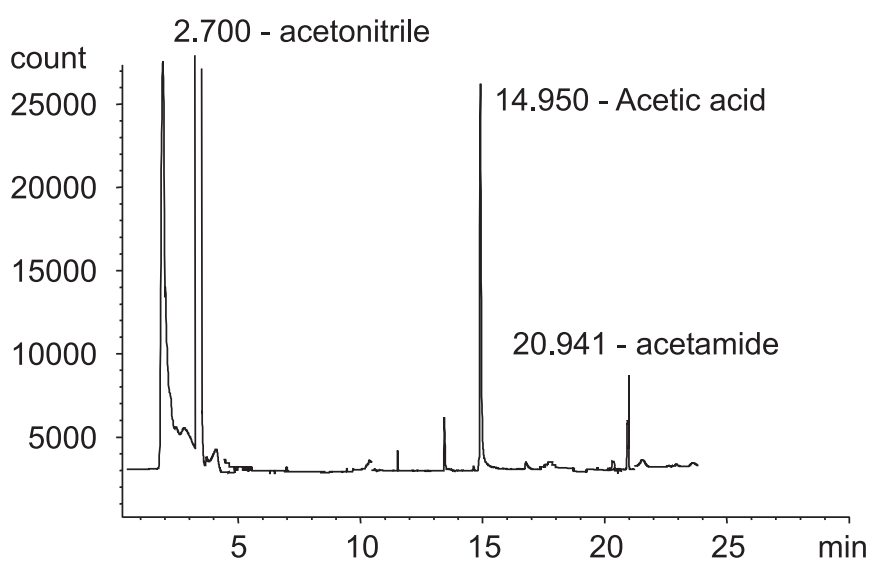

Figure 4. Enzymatic assay with intact cells of Geotrichum sp. JR1 showing acetonitrile breakdown (retention time 2.700) yielding acetic acid (retention time 14.950) and acetamide (retention time 20.941), suggesting the presence of nitrile hidratase - amidase system.

shown) indicates the potential use of this organism in the treatment of toxic wastes containing nitrile. It could also be used for acid and amide bioproduction.

Others yeast strains have been studied for nitrile degradation. Some yeast cultures have the capacity to use nitriles as nitrogen sources (9). Studies on yeast immobilization for nitrile degradation have been made $(3,4)$, but this work is the first to report on a yeast able to use nitrile at high concentrations as its sole nitrogen and carbon source.

\section{ACKNOWLEDGMENTS}

This research has been awarded grants from Conselho Nacional de Desenvolvimento Científico e Tecnológico (CNPq) (Proc.523158/96), Fundação de Apoio à Pesquisa do Estado de Minas Gerais (FAPEMIG) (CBS 1001/97). Special thanks to Universidade Estadual de Santa Cruz and Universidade Federal de Minas Gerais.

\section{RESUMO}

\section{Uso de acetonitrila como única fonte de carbono e nitrogênio por Geotrichum sp. JR1}

Uma linhagem de levedura identificada como Geotrichum sp. JR1 foi capaz de utilizar acetonitrila, em concentrações de 0,5 a $2 \mathrm{M}$, como única fonte de carbono e de nitrogênio. A geração de amônia durante o crescimento do microrganismo indica a presença de sistema enzimático capaz de degradar acetonitrila. Durante os ensaios enzimáticos, com células 
cultivadas em acetonitrila, foram detectados ácido acético e acetamida como produtos indicando a presença de sistema enzimático capaz de degradar acetonitrila e acetamida. Este trabalho é o primeiro a descrever a utilização de acetonitrila como única fonte de carbono e de nitrogênio por uma levedura.

Palavras-chave: Geotrichum sp., acetonitrila, enzimas de degradação

\section{REFERENCES}

1. Asano, Y.; Tani Y.; Yamada, H. A new enzyme "nitrile hydratase" which degrades acetonitrile in combination with amidase. Agric. Biol. Chem., 44: 2251-2252, 1980.

2. Dias, J.C.T.; Rosa, C.A.; Linardi, V.R. Yeasts tolerant to cyanometal complexes isolated from a gold mining plant. In: Gaylarde C.C.; Saccol de Sa E.L. (eds.) LABS 2-Biodegradation and Biodeterioration in Latin America. Unep/Unesco/UFRGS, Brazil, 1996, p.154-155.

3. Dias, J.C.T.; Rezende, R.P.; Linard, V.R. Biodegradation of acetonitrile by cells of Candida guilliermondii UFMG-Y65 immobilized in alginate, K-carrageen and citric pectin. Braz. J. Microbiol., 31: 61-66, 2000a.
4. Dias, J.C.T.; Rezende, R.P.; Rosa, C.A.; Lachance, M.A.; Linard, V.R. Enzymatic degradation of nitriles by a Candida guilliermondii UFMG-Y65. Can. J. Microbiol., 46: 525-531, 2000b.

5. Fawcet, J.K.; Scott, J.E. A rapid and precise method for the determination of urea. J. Clin. Pathol., 13: 156-159, 1960.

6. Jallageas, J.C.; Arnaud, A.; Galzy, P. Bioconversions of nitriles and their aplications. Adv. Biochem. Eng., 14: 1-31, 1980.

7. Kobayashi, M.; Nagasawa, T.; Yamada, H. Nitrilase of Rhodococcus rhodochrous J1. Purification and charaterization. Eur. J. Biochem., 182: 349-356, 1989.

8. Kurtzman, C.P.; Fell, J.W. The Yeast - A taxonomic study. Elsevier Science B.V., Amsterdan, 1998.

9. Linardi, V.R.; Dias, J.C.T.; Rosa, C.A. Utilization of acetonitrile and other aliphatic nitriles by a Candida famata strain. FEMS Microbiol. Lett., 144: 67-71, 1996.

10. Nagasawa, T.; Yamada, H. Microbial transformations of nitriles. Trends Biotechnol., 7: 153-158, 1989.

11. Nawaz, M.S.; Chapatwala, K.D.; Wolfran, J.H. Degradation of acetonitrile by Pseudomonas putida. Appl. Environ. Microbiol., 55: 2267-2274, 1989.

12. Rezende, R.P.; Dias, J.C.T.; Rosa, C.A.; Carazza, F.; Linardi, V.R. Utilization of nitriles by yeasts strains isolated from a Brazilian gold mine. J. Gen. Appl. Microbiol., 45: 185-192, 1999.

13. Wyatt, J.H.; Knowles, C.J. Microbial degradation of acrylonitrile waste effluents: the degradation of effluents and condensates from the manufacture of acrylonitrile. Intern. Biodet. Biodeg., 227-248, 1995. 